\title{
Soil Ingestion by Cattle on Semiarid Range as Reflected by Titanium Analysis of Feces
}

\author{
H. F. MAYLAND, A. R. Florence, R. C. ROSENAU, V. A. LAZAR, AND H. A. TURNeR
}

Highlight: Soil ingestion was determined for cattle grazing $a$ Bromus tectorum range in southern Idaho by measuring titanium concentrations in animal feces collected at 2-week intervals during the droughty 1973 grazing season. The experiment was based on the premise that titanium, which is abundant in soils, is contained only in small quantities /less than $1 \mathrm{ppm}$ ) in plants not contaminated with soil.

Fecal-soil values averaged $14 \%$, with values ranging from 3 to $30 \%$ of fecal dry matter, increasing as forage availability decreased. Soil ingestion levels were estimated to range from 0.1 to $1.5 \mathrm{~kg}$ with a median of $0.5 \mathrm{~kg}$ soil/animal-day. This soil was ingested primarily with the roots of Bromus tectorum, which were often pulled up and consumed with the aboveground plant parts. Dust on leaves and stems accounted for only a small portion of the ingested soil.

Measurements of acid-insoluble residue concentration in feces overestimated soil ingestion because of the probable presence of $\mathrm{SiO}_{2}$ of plant origin. Large changes in forage $\mathrm{SiO}_{2}$ concentrations of the diet reduce the effectiveness of this method compared to the Ti method.

Ingested soil may be a possible source of trace minerals, pesticides, heavy metals, and radionucleides that may be sorbed to surface soil particles.

Ingested soil may be a source of minerals to the grazing ruminant. Its importance depends on the amount of soil ingested, the ratio of the mineral concentration in soil to that in herbage, and the ability of the ruminant to solubilize and absorb the soil-derived minerals.

We were motivated to consider ingested soil as a dietary zinc $(\mathrm{Zn})$ source because we did not find visual $\mathrm{Zn}$ deficiency symptoms in cattle whose diet did not otherwise appear to contain adequate $\mathrm{Zn}$. The possibility that ingested soil may be a source of dietary minerals for grazing sheep and cattle has been investigated in New Zealand (Healy, 1967, 1968, 1973). Healy et al. (1970) reported that about $14 \%$ of the radioactive ${ }^{65} \mathrm{Zn}$ adsorbed to soil was absorbed by experimental sheep after they were drenched with $100 \mathrm{~g}$ of the ${ }^{65} \mathrm{Zn}$ labelled soil.

Authors are soil scientist and research technicians, Snake River Conservation Research Center, Kimberly, Idaho, 83341; soil scientist, U.S. Plant, Soil and Nutrition Laboratory, Ithaca, New York, 14850; and assistant professor, animal nutrition, Oregon State University, Burns, Oregon, 97720 .

This research was performed under CRIS Work Unit No. 5704-12320-002 and is a contribution from the Western Region, Agricultural Research Service, U.S. Department of Agriculture; Bureau of Land Management, U.S. Department of the Interior; and Oregon and Idaho Agricultural Experiment Stations cooperating.

The authors appreciate the cooperation of $R$. C. Bull, animal nutritionist, University of Idaho; Herb Edwards, Elmore County Agricultural Extension Agent; and Randy Jackson, Daryl Keck, Bill Pruett, Ray Thompson, and Lee Trail for providing the cattle and labor. Manuscript received December 26, 1974.
The objective of this study was to determine soil ingestion rates for cattle grazing on a semiarid range in southern Idaho.

\section{Field Methods}

The study was conducted on the Saylor Creek Experimental Range, 7 miles southwest of Glenns Ferry, Ida. It is a mesic, upland site with a coarse silty, xerollic durorthid soil classified in the Minidoka silt loam soil series. The area receives 130 to $330 \mathrm{~mm}$ annual precipitation with a mean of $220 \mathrm{~mm}$. Precipitation during 1973 was $200 \mathrm{~mm}$, with only 80 $\mathrm{mm}$ occurring between March 1 and October 31. The native big sagebrush-Thurber needlegrass complex (Artemisia tridentata-Stipa thurberiana) has been largely replaced by cheatgrass (Bromus tectorum).

In mid-June 1973 , four groups of 25 cow-calf pairs each were assigned to individual 32.4 ha ( 80 acre) pastures (Fig. $1 \mathrm{~F})$. After each group utilized an estimated $70 \%$ to $80 \%$ of the forage in that pasture, it was given access to an additional pasture(s). A fifth group, also having 25 cow-calf pairs, was assigned to a large 150-ha pasture for the entire study (Pasture LP, Fig. 1F). Feces, distinguished as to cow or calf origin, were sampled from the five groups at 2-week intervals from July 3 through November 6 . Fecal subsamples were taken from the center of approximately 10 fresh dung pats, carefully avoiding soil and dust contamination; subsamples were composited by group.

Forage, clipped at a $2-\mathrm{cm}$ stubble height, was collected at regular intervals. During the grazing season, six forage samples were pulled in a sweeping motion and shaken to simulate material eaten by cattle. The simulated samples contained attached crowns, roots, and soil. The forage and fecal samples were dried at $65^{\circ} \mathrm{C}$ for 72 hours and ground in stainless steel equipment to pass a 20 -mesh screen.

Soil samples representing less than $0.58 \mathrm{~mm}$ material in the $0-$ to $2-\mathrm{cm}$ depth were collected from Pastures 47, 50, 54, 57, and 61 (Fig. 1F) and air dried.

\section{Laboratory Methods}

\section{Titanium Method}

The experimental approach was based on the premise that titanium (Ti), which is abundant in soils $(1,000$ to $3,000 \mathrm{ppm}$ $\mathrm{Ti}$ ), is contained only in small quantities (less than $1 \mathrm{ppm} \mathrm{Ti}$ ) in plants not contaminated with soil (Healy, 1968). Soil concentration in fecal and plant material was, therefore, determined by spectrographically measuring the amount of $\mathrm{Ti}$ present. Samples were loosely packed in aluminum frames, backed with $0.06 \mathrm{~mm}$ mylar film, and subjected to an $\mathrm{x}$-ray fluorescence instrument with a tungsten target tube and a sodium chloride analyzing crystal. Samples and optical path were bathed with a helium atmosphere. 

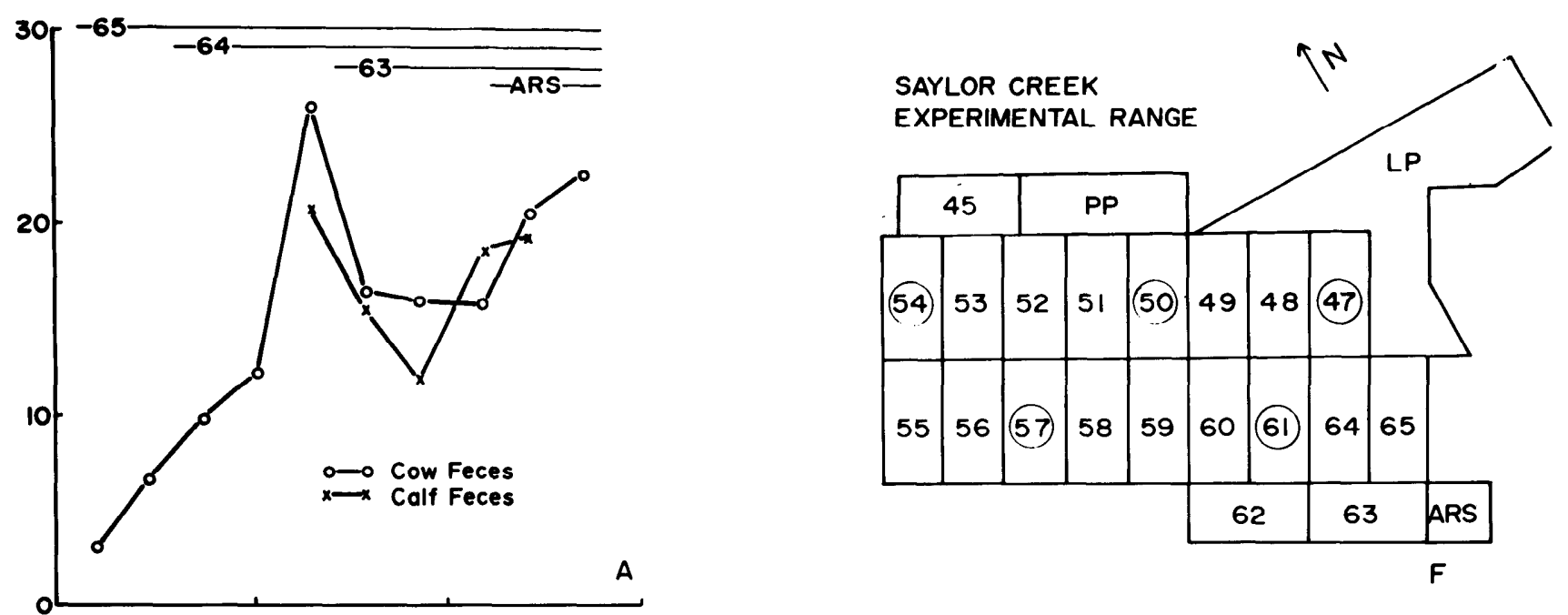

$A$

$\mathbf{F}$
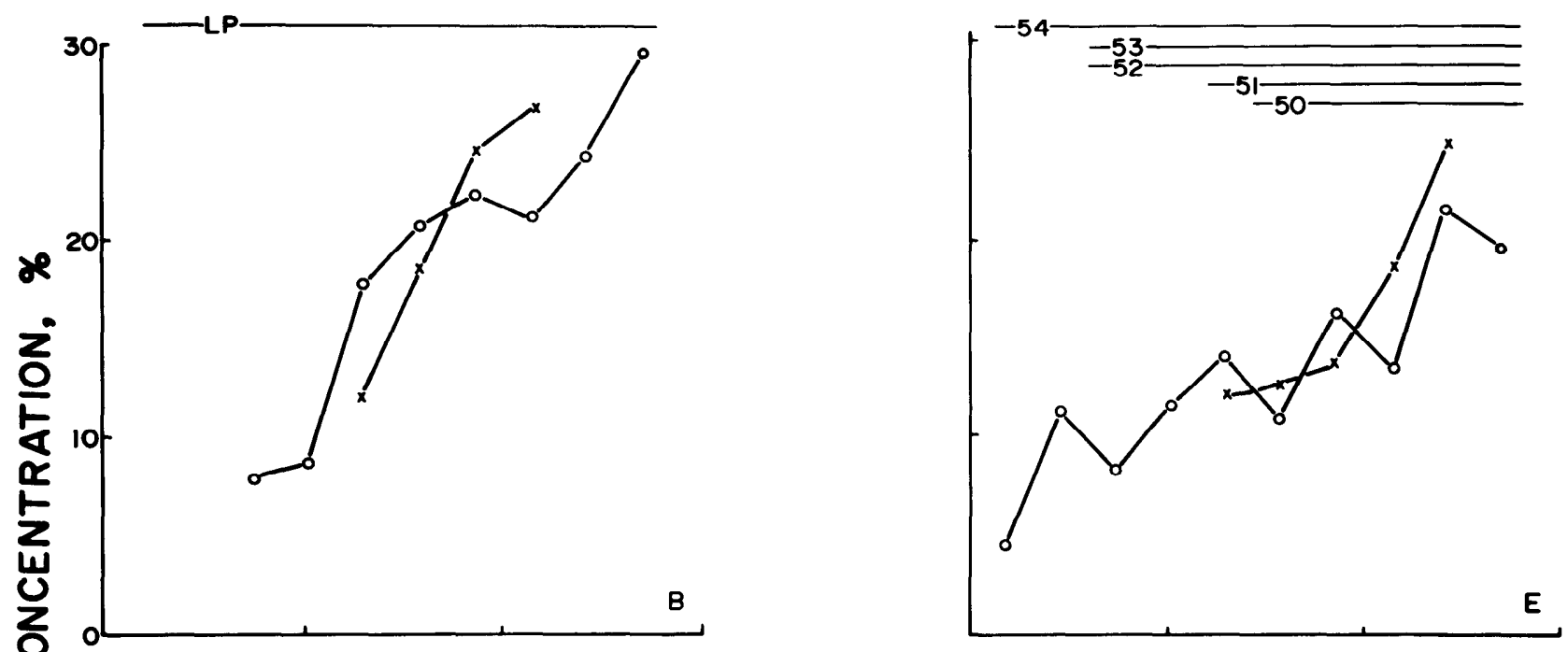

峁

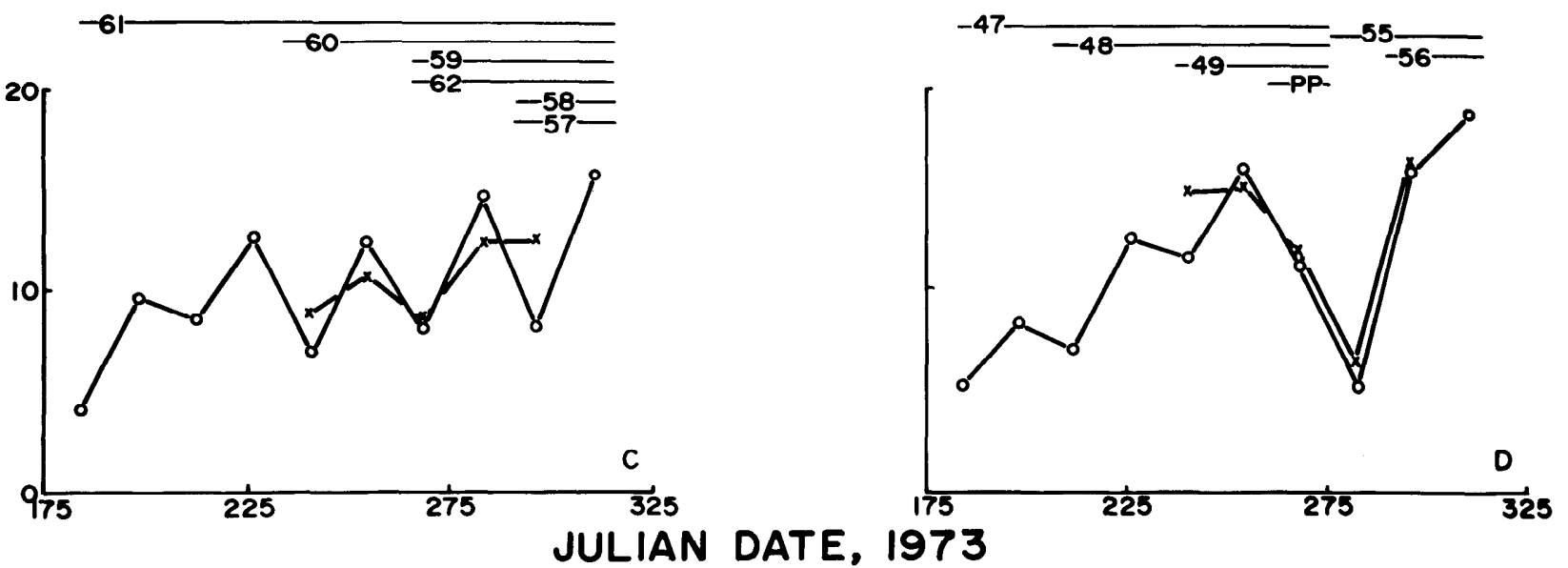

Fig. 1. Fecal-soil concentration of five cow-calf groups as related to Julian date and pasture accessibility. The horizontal line or lines on the top of each sub-figure indicate the time duration during which that cow-calf group had access to the designated pastures. The experimental pasture arrangement is shown in Figure IF. All pastures are 32 ha (80 acres), except LP=150 ha (375 acres) and ARS $=16$ ha (40 acres).

The ratio $\mathrm{F} / \mathrm{S}$, where $\mathrm{F}$ is the counting rate at the Ti $\mathrm{K} \alpha$ emission line $\left(\lambda=2.750 \AA, 2 \theta=58.34^{\circ}\right)$, and $S$ is the counting rate at the background $\left(\lambda=3.267 \AA, 2 \theta=71.00^{\circ}\right)$ was used as a measure of the $\mathrm{Ti}$ concentrations in fecal, plant, and soil samples. In previous studies, this ratio was found to be a better measure of the concentrations of elements in the parts per million range than either the counting rate at the $\mathrm{Ti} \mathrm{K} \alpha$ line less rounting rate at the background $(F-S)$, or the counting rate at the Ti K $\alpha$ line (F) by itself (Kubota and Lazar, 1971). Calibration for Titanium Method

The $\mathrm{Ti}$ concentration in soils was determined by the method of additions. The spectrographic parameter $F / S$ was 
linearly related to $\mathrm{TiO}_{2}$ additions in the range of 0 to 6,000 ppm Ti $(r=0.99$, standard error $=30 \mathrm{ppm} \mathrm{Ti})$. Soils from Pastures 50, 54, and 57 were calculated to contain $2,400 \mathrm{ppm}$ $\mathrm{Ti}$, while those from Pastures 47 and 61 contained 2,100 and $2,200 \mathrm{ppm} \mathrm{Ti}$, respectively. The soil from Pasture 57 was chosen for further calibration, realizing that estimates of soil content in forage and feces collected from the eastern part of the experimental area would be underestimated by 5 to $10 \%$.

A standard fecal-soil series was prepared by thoroughly mixing known amounts of soil from Pasture 57 (Fig. 1F) with a dry "control" fecal sample obtained from a stall-fed cow receiving cured timothy hay. Since only a trace of $\mathrm{Ti}$ was measured in the "control" by x-ray spectrographic scan, it was ascertained to contain less than $0.1 \%$ soil. Fecal-soil concentration was curvilinearly related to the spectrographic expression F/S (Fig. 2) having an error of $0.35 \%$ soil. Soil concentration in field samples would have an expected standard error of $0.7 \%$ soil because unknowns had been thoroughly mixed 1:1 with the "control" feces to reduce the errors derived from differences in matrix effects between field and "control" samples.

A standard forage-soil series was prepared as above, except that a wheatgrass (Agropyron desertorum) sample was used instead of the "control" feces. The Ti concentration in the wheatgrass sample was determined by the method of soil additions. Clipped plant samples were mixed 1:1 with the wheatgrass sample before analysis.

\section{Acid-Insoluble Residue Method}

The acid-insoluble residue content of plant and fecal samples was determined by dry-ashing 10 -g samples at $550^{\circ} \mathrm{C}$ for 6 hours. The cooled ash was moistened with water, acidified with $20 \mathrm{ml}$ concentrated $\mathrm{HCl}$ to remove carbonate, taken to dryness on hot plate, redissolved in $50 \mathrm{ml} 2 \mathrm{~N} \mathrm{HNO}_{3}$, and diluted to approximately $100 \mathrm{ml}$ with water. The sample was washed onto Whatman No. 1 filter paper and the residue washed with about $50 \mathrm{ml}$ additional water. The filter paper and residue were ashed at $550^{\circ} \mathrm{C}$ for 4 hours and the cooled ash was moistened with water, acidified with $2 \mathrm{ml}$ concentrated $\mathrm{HCl}$, and taken to dryness. The residue was weighed and calculated as percent acid-insoluble residue of the original sample.

Forage dry matter digestibility was determined by the in vitro technique of Tilley and Terry (1963) as modified by Kartchner (1975).

\section{Results and Discussion}

Clipped grass samples of wheatgrass, cheatgrass, bluegrass (Poa secunda), needleand thread (Stipa comata) and squirreltail (Sitanion hysterix) contained up to about $0.4 \%$ soil, with several samples having as much as $0.7 \%$ soil. Animal consumption of clipped forage with an assumed $66 \%$ dry matter digestibility would yield feces containing up to $2 \%$ soil. Thus, soil attached to aboveground plant parts does not seem to have contributed much to fecal-soil concentrations in this study.

Soil concentrations in the pulled cheatgrass samples ranged from 13 to $18 \%$. Ingestion of the forage samples pulled to simulate livestock grazing would, under the above conditions, produce feces containing about $30 \%$ soil. Thus, fecal-soil concentrations in excess of $2 \%$ probably originate from soil adhering to ingested stem bases and roots or from direct soil ingestion.

Fecal-soil concentrations ranged from 3 to $30 \%$ during the droughty 1973 season (Fig. 1A-E), and generally increased as the amount of available forage decreased. When animals were given access to previously ungrazed pastures, fecal-soil concentrations would decrease. For example, cows grazing
Pastures 64 and 65 on day 240 were excreting feces containing $26 \%$ soil (Fig. 1A). However, after cattle were given access to Pasture 63, average soil concentrations in the feces decreased to about $16 \%$. The abundant forage in this pasture was probably responsible for maintenance of similar soil ingestion levels for two additional sampling periods. Cattle in the LP pasture had access to more feed than did other groups, but it is believed that they may not have used it efficiently because of the irregular pasture perimeter (Fig. 1B). The calf data for fecal-soil concentrations were generally similar to those for cows (Fig. 1A-E).

Healy $(1967,1968)$, who reported on soil ingestion studies in sheep and dairy cows grazing humid pastures in New Zealand, found that cows ingested from 0.25 to $1.25 \mathrm{~kg}$ soil/animal-day. The amount was roughly proportional to stocking intensity and closeness of grazing, and inversely proportional to available forage and soil structure. Muddying of forage by trampling, raindrop splash, and earthworm casts was an indirect factor affecting soil ingestion levels in the New Zealand studies.

Muddying of forage was definitely not a contributing factor in the Idaho study since soils remained dry during the July to November period. Grass forage was mature and cured during much of this period. Dry soil particles may have been attached to the leaves and stems but would not have accounted for more than $2 \%$ soil concentration in the feces (see previous discussion). Fecal-soil concentrations in this study are likely related to closeness of grazing, forage availability, and shallow rooted plants. Cattle easily pulled the shallow-rooted cheatgrass plants from the dry silty soils along with portions of

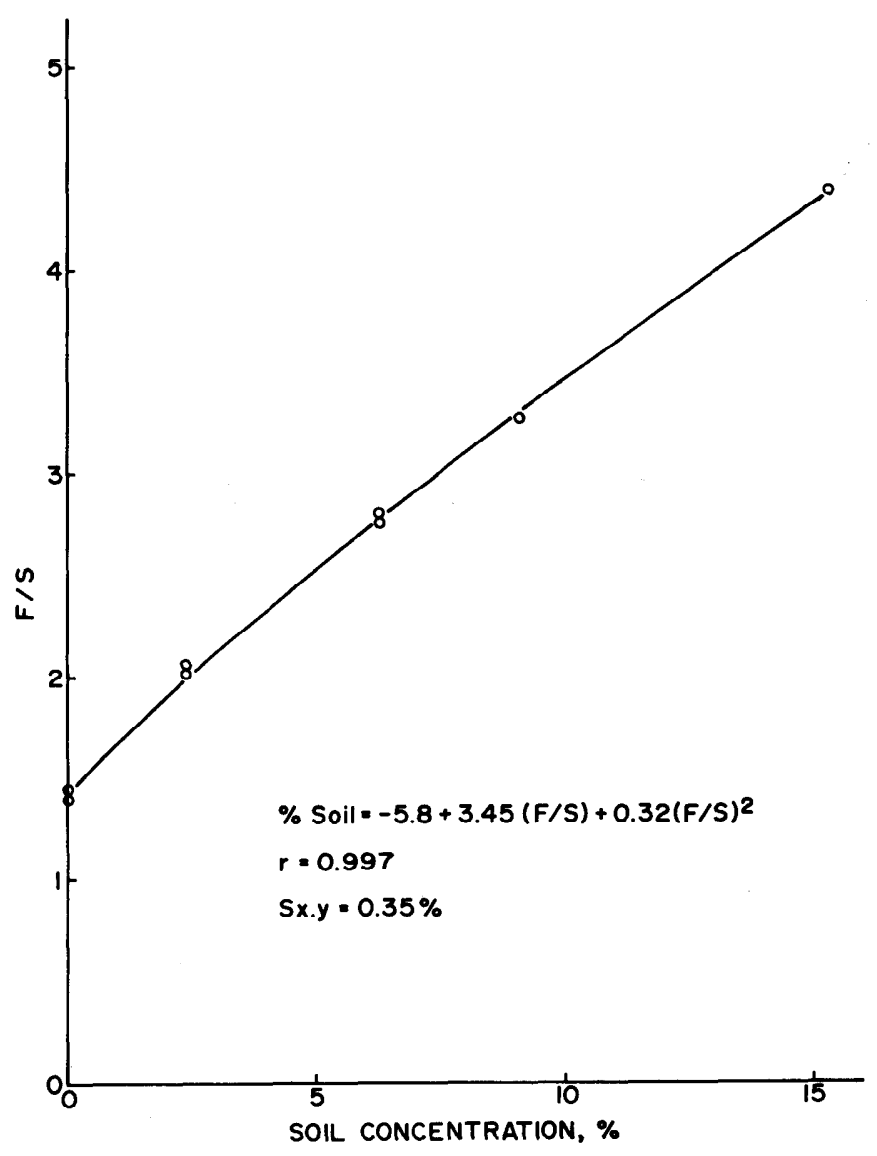

Fig. 2. Fecal-soil concentrations in relation to the spectrographic expression $F / S$. 


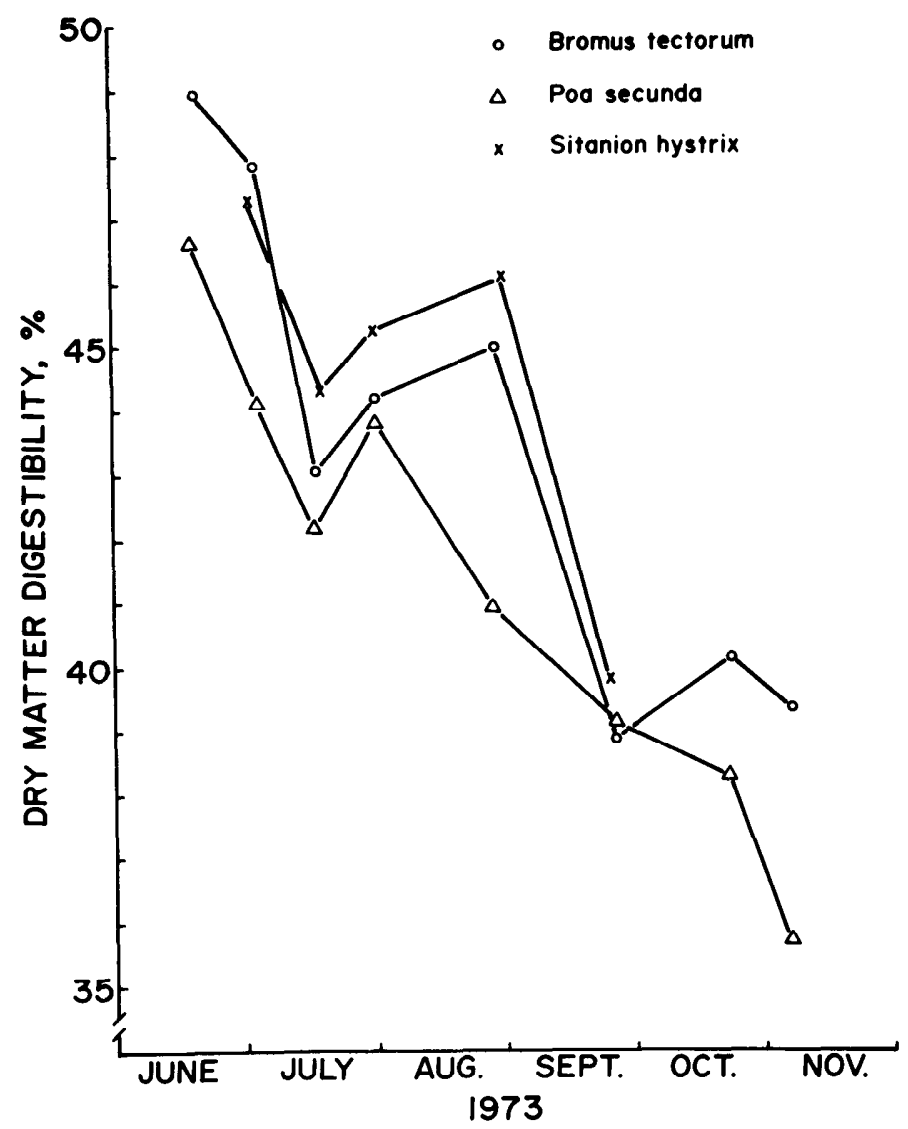

Fig. 3. In vitro dry matter digestibility values for three forage species grazed on the Saylor Creek Experimental Range in 1973.

roots and attached soil. Animals would occasionally drop that portion of the bite having a large amount of soil. Forage samples pulled from the soil to simulate grazing were calculated to produce a fecal soil concentration of about $35 \%$ (assuming a $50 \%$ dry matter digestibility). This value is considerably greater than the maximum values shown in Fig. $1 \mathrm{~A}-\mathrm{E}$, indicating some discrimination against the ingestion of plant parts containing the amount of soil normally adhering to crowns and roots.

The data presented thus far represent soil concentration measured in the feces. Dry matter intake and digestibility must also be known in order to calculate actual soil ingestion levels. In vitro dry matter digestibility of forage samples collected throughout the 1973 grazing period (Fig. 3) and in vivo data obtained from a 1970 study of steers grazing Pasture 65 (Olsen, 1971) will be used to provide this additional information. Steer weights were 222,248 , and $274 \mathrm{~kg}$; dry matter intake was $5.0,5.0$, and $6.8 \mathrm{~kg}$ per day; and dry matter digestibility was 72,63 , and $66 \%$ for early, mid-, and late summer periods, respectively (Olsen, 1971). Cows used in the present study weighed 300 to $450 \mathrm{~kg}$ and were assumed to have a dry matter intake of 7 to $9 \mathrm{~kg} / \mathrm{cow}$-day. Forage in the 1973 study was probably less digestible than that reported by Olsen, especially for the early summer period because of earlier forage maturity in 1973. This contention is supported by the in vitro dry matter digestibility data obtaincd on the 1973 clipped forage samples (Fig. 3).

The following example is given for calculating soil ingestion levels when forage dry matter digestibility is $50 \%$. The non-soil fecal mass is calculated as:

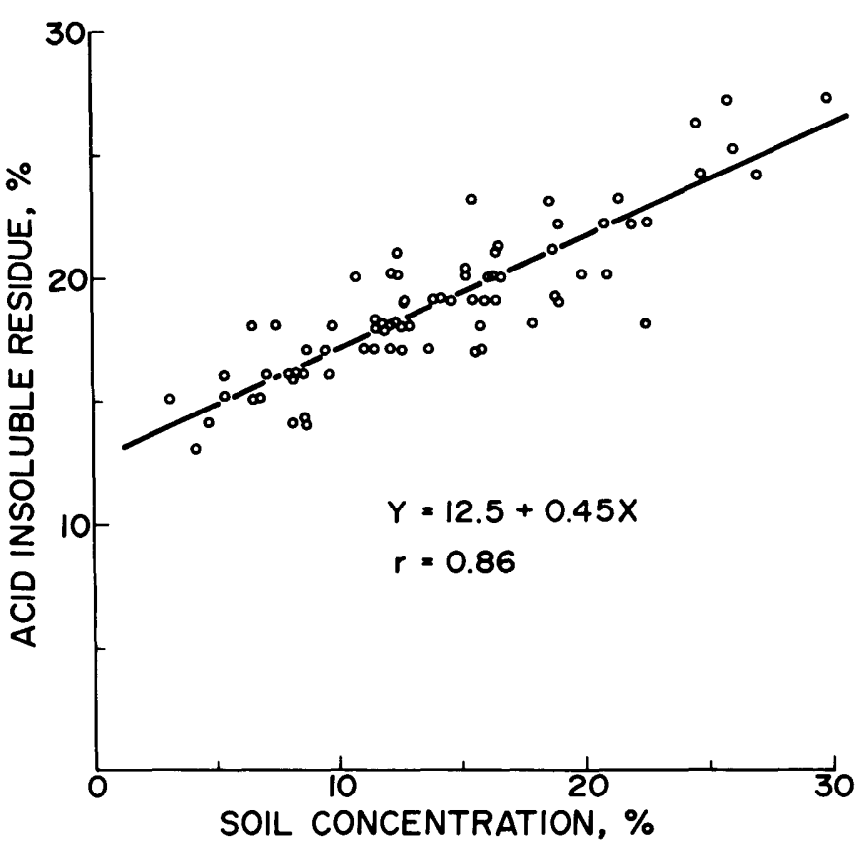

Fig. 4. Acid-insoluble residues in fecal samples as related to soil concentration values determined by the titanium method.

(9 kg DM intake) - [(0.50 digestible) (9 kg DM)] $=4.5 \mathrm{~kg}$ fecal mass of plant origin

Fecal-soil concentrations given in Figure 1A-E are based on soil plus organic matter. Therefore, if the fecal sample contains $10 \%$ soil (organic matter fraction $=0.9$ ), the total fecal excretion is:

$$
\begin{aligned}
& \text { (4.5 kg fecal organic matter) } / 0.9=5.0 \mathrm{~kg} \\
& \text { fecal-soil plus fecal mass of plant origin }
\end{aligned}
$$

The mass of soil ingested is:

$$
\begin{gathered}
5.0 \mathrm{~kg} \text { total excretion }-4.5 \mathrm{~kg} \text { excreted fecal } \\
\text { mass of plant origin }=0.5 \mathrm{~kg} \text { soil ingested }
\end{gathered}
$$

Table 1 gives soil ingestion levels for two dry matter intake rates and four dry matter digestibilities. The calculated values range from a low of 0.1 (early in the season) to as much as 1.5 $\mathrm{kg}$ soil ingested/animal-day (later in the grazing season). These values compare reasonably well to those of Healy (1968), who reported a range of 0.25 to $1.25 \mathrm{~kg}$ soil/animal-day for dairy cows on humid pastures.

Silica $\left(\mathrm{SiO}_{2}\right)$ concentrations or acid-insoluble residues (Healy, 1973) in feces are possible indicators of soil ingestion levels. Acid-insoluble residue of feces versus soil concentration values determined by the Ti method are given in Figure 4 . The $Y$ intercept of about $13 \%$ represents a residue of plant origin, largely $\mathrm{SiO}_{2}$. That the regression coefficient is not 1.0 indicates large variations in the dietary intake of insoluble plant residue.

Table 1. Soil ingestion levels (kg/animal-day) for a $10 \%$ soil increment found in feces calculated for two dry-matter intake levels and four dry-mat ter digestibility levels.

\begin{tabular}{ccccc}
\hline \hline \multirow{2}{*}{$\begin{array}{c}\text { Dry matter } \\
\text { intake }\end{array}$} & \multicolumn{4}{c}{ Dry matter digestibility } \\
\cline { 2 - 5 } & $40 \%$ & $50 \%$ & $60 \%$ & $70 \%$ \\
\hline 7 & 0.47 & 0.39 & 0.31 & 0.23 \\
9 & 0.60 & 0.50 & 0.40 & 0.30 \\
\hline
\end{tabular}




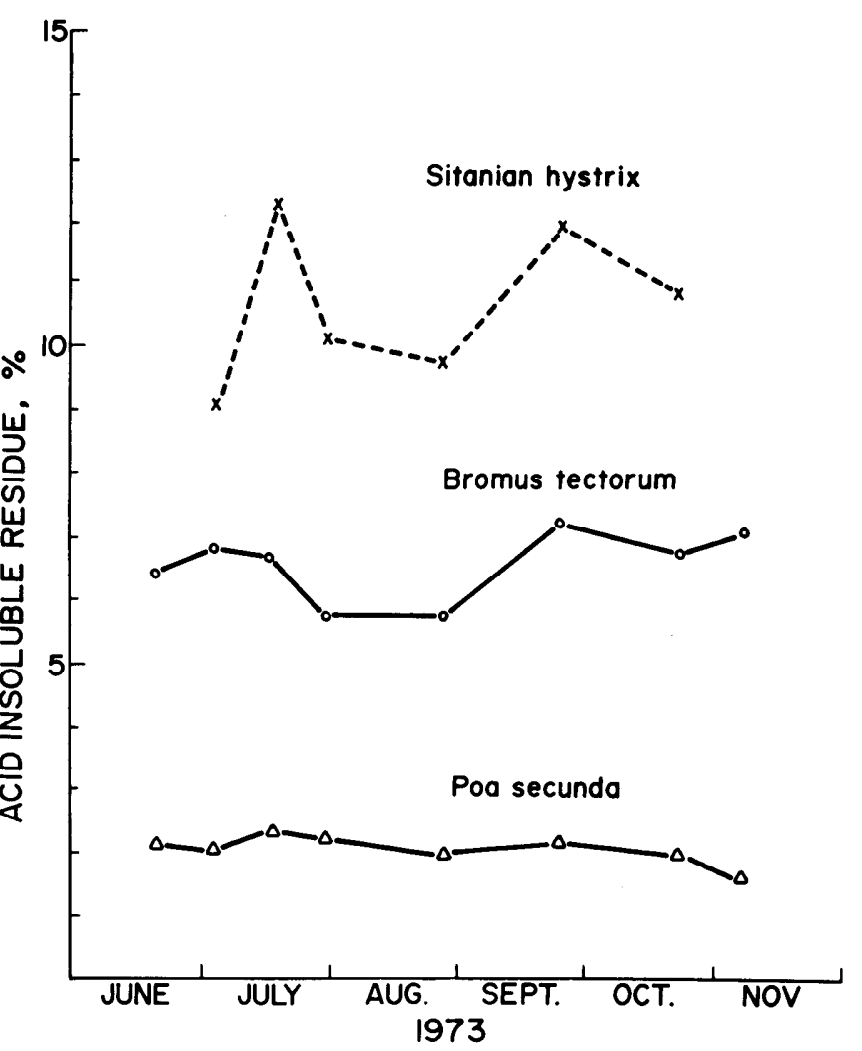

Fig. 5. Acid-insoluble residues in three forage species grazed on the Saylor Creek Experimental Range in 1973.

Significant differences in the acid-insoluble residue of the three major forage species from the study area are shown in Figure 5. A diet of Bromus tectorum having a 50\% dry matter digestibility would result in a 12 to $14 \%$ acid-insoluble residue predicted at the $0 \%$ fecal soil concentration (Fig. 4), but does not explain the 0.5 regression coefficient. About 75 to $85 \%$ of the forage in the study area was Bromus tectorum, but the inclusion of other grasses in the diet could greatly change the amount of insoluble residue of plant origin which would then appear in the feces.

Thus the acid-insoluble residue or $\mathrm{SiO}_{2}$ concentrations in feces are subject to large changes in forage $\mathrm{SiO}_{2}$ concentrations of the diet. These changes reduce the effectiveness of these two methods for determining soil concentrations in feces and ultimately the level of soil ingestion by animals.

The cattle in this study were ingesting significant amounts of soils. How important this soil ingestion is in contributing to the trace mineral requirement will depend on soil properties (Healy, 1973). Soil ingestion may also be important for uptake of toxic elements, i.e., cadmium, lead, mercury, pesticides, and radionucleides, which are concentrated in the upper few centimeters of soil.

The overall impact of these findings is that a direct soil-animal interrelationship must be considered.

\section{Literature Cited}

Healy, W. B. 1967. Ingestion of soil by sheep. New Zealand Soc. Anim. Prod. 27:109-120.

Healy, W. B. 1968. Ingestion of soil by dairy cows. New Zealand J. Agr. Res. 11:487-499.

Healy, W. B. 1973. Nutritional aspects of soil ingestion by grazing animals, p. 567-588. In: G. W. Butler and R. W. Bailey (ed.), Chemistry and biochemistry of herbage. Academic Press, New York.

Healy, W. B., W. J. McCabe, and G. F. Wilson. 1970. Ingested soil as a source of microelements for grazing animals. New Zealand J. Agr. Res. 13:503-521.

Kartchner, R. J. 1975. Forage intake and related performance criteria of spring and fall calving cow-calf pairs on summer rangc. $\mathrm{PhD} \mathrm{D}$ iss. Oregon State Univ.

Kubota, Joe, and V. A. Lazar. 1971. X-ray emission spectrograph: Techniques and uses for plant and soil studies, p. 67-82. In: Instrumental methods for analysis of soils and plant tissue. Soil Sci. Soc. Amer., Madison, Wisconsin, publ.

Olsen, Thomas E. 1971. Utilization and supplementation of cheatgrass in southern Idaho. MS Thesis, Univ. of Idaho. $52 \mathrm{p}$.

Tilley, J. M. A., and R. A. Terry. 1963. A two-stage technique for the in vitro digestion of forage crops. J. Brit. Grassl. Soc. 18:104-111. 